Priemus H., Conijn J., Dieleman F. and Hooimeijer P. (1992)

Housing models : methodology, scope and applications. Journal of Housing and the Built Environment 7(1), 5-7 


\title{
HOUSING MODELS: METHODOLOGY, SCOPE AND APPLICATIONS
}

\author{
Hugo Priemus, Johan Conijn, Frans Dieleman and Pieter Hooimeijer
}

The European Network for Housing Research embraces a Working Group on Housing Models. Members of this working group conduct studies in which they apply quantitative models. The aim of these studies is to quantify the effects of policy change and market fluctuations. Housing models are eminently suited to assess the effects of policy on housing market processes: alternatives can be compared, and impact analysis can be carried out. Housing models may play a role in demographic, economic and policy analysis. During the International Housing Research Conference 'Housing Debates, Urban Challenges', which was held in Paris July 3-6, 1990, the ENHR Working Group held a workshop on the theme "Housing Models: Methodology, Scope and Applications." That workshop laid the foundation for this special issue of The Netherlands Journal of Housing and the Built Environment (H\&E).

In this 'special', H\&E collates five papers that employ economic models to analyse housing issues. These contributions give some indication of the current methodology, scope and applications of housing models, at least in the areas of economics and policy studies.

The article "Housing demand and tenure choice: evidence from Finland," Loikkanen (Finland) estimates the tenure-specific housing demand, broken down by dwelling size. His estimate is the result of a two-stage estimation procedure performed on data from the Finnish Household Expenditure Survey (1985). Tenure choice and demand for dwelling size are related to three household variables: income, household structure and life cycle. The model is differentiated regionally by drawing a comparison between regional house prices and rents. Rent policy plays a major role in this differentiation. The more households in the queue for publicly allocated rented dwellings, the greater the probability of ownership is estimated to be. No relation is supposed between rental queue and the demand for dwelling size.

Micro-level income (a proxy for tax effects), household structure and life cycle variables appear to affect demand decisions, both for tenure and dwelling size. The regionally determined relation between (asset) price of owner-occupied dwellings and rent level negatively affects the probability of owning. Regional house prices have a negative effect on the demand of owner-occupants for dwelling size; regional

Neth. J. of Housing and the Built Environment, Vol. 7 (1992) No. 1. 
rent levels do not affect the tenants' demand for dwelling size. The length of the rental queue provides the anticipated push effect toward ownership. On the other hand, the demand for owner-occupied dwelling size is negatively affected by the rental queue, which was not expected. Contrary to the expectations of the author, there is no relation between rental queue and the demand for rented dwelling size.

Guissani and Hadjimatheou (UK) present an econometric model for the housing market of the United Kingdom. They use a co-integration analysis, paying particular attention to the integration of demand and supply considerations, as suggested by economic theory. With the aid of quarterly data for the period 19611988 , both long-term developments and short-term dynamics of house prices can be explained. The authors consider the model especially suited for forecasting purposes. The number of households, amount of personal disposable income per capita, house building costs, and size of the housing stock are considered to be the driving forces behind long-run developments in house prices. House prices show a disproportionately higher increase than income and number of households. And house prices increase disproportionately less than the cost of housing construction. Increments in the housing stock reduce house prices disproportionately much. Rents have a significant impact on the dynamics of house prices. In the short run, these dynamics are affected by recent movements in house prices, change in the inflation of house prices, the stock and flow of building society mortgages, bank lending, the number of completions, and the ratio of households to housing stock (which is a measure of the tightness of the housing market). Fiscal and monetary policy have a direct impact on house prices through changes in personal disposable income, interest rates, and the tax allowance of mortgage interest payments.

Rouwendal (The Netherlands) presents the hedonic price function as an envelope of bid functions. He outlines an alternative to Rosen's two-stage approach to the analysis of markets for differentiated products. He used data from the 1981 Housing Needs Survey in The Netherlands. The hedonic price function has been modelled as the envelope of a set of bid functions. This method circumvents the second stage of Rosen's approach, as well as the econometric problems associated with this second stage. Admittedly, the equation he estimates may be complicated, but its estimation remains conceptually simple. Another advantage of the procedure introduced by Rouwendal is the ease with which he deals with indivisible aspects of the commodity 'housing'. The usual approach relies more heavily on marginal conditions.

Turner, Berger and Waller (Sweden) present a microsimulation model of distributional and dynamic effects of rent decontrol in Sweden. They analyse the present rent control system in Sweden in order to assess the effects of rent decontrol. The study, which is limited to the Stockholm region, predicts rent increases in the central urban areas. The study focuses on the shift in demand for dwellings of different sizes. The authors use data from the Swedish Housing and Rent Survey (1987). The empirical section of the paper starts with a hedonic analysis of housing expenditure in cooperative dwellings in the Stockholm area. Variation in rent level is explained by dwelling characteristics and locational data. Estimates from the cooperative sector are used to calculate a likely market rent for 
rental dwellings. It is assumed that both sectors are close substitutes. The difference between the calculated market rents and the controlled rents is determined. This gap varies from zero to $60 \%$ of the controlled rents. The widest gap applies to older, centrally located dwellings. A strong positive correlation between the rent gap and household income could be demonstrated. Households with the highest income derive the greatest advantage from rent control, which is a remarkable distributional effect. Finally, the probability of moving as a result of a rent increase is estimated. The resulting effects on housing expenditure and consumption are calculated.

In the last contribution, "Decision plan nets and expert system tools: a new combination for application-oriented modelling of choice behaviour," Op 't Veld, Bijlsma and Starmans (The Netherlands) report on an investigation of the possibilities offered by decision plan nets as a decision-support system. The authors derived decision plan nets for young households from the urban area in and around The Hague who were interested in buying a single-family home.

A decision plan net is characterized by a decision tree. The first step in filling this tree is to establish which attributes influence the decision-maker, in this case the home-seeker. The importance of each attribute is measured, taking the relation with other attributes of the dwelling into account. A dwelling lacking a particular attribute may be rejected or, alternatively, may only be acceptable in combination with other attributes. On the basis of the interviews, a picture emerges of the composition of the housing supply desired by a group of respondents.

Decision plan nets allow us to compare housing demand to housing supply, in its quantitative and qualitative variants. Furthermore, the system of decision plan nets is user-friendly, requiring little prior knowledge to apply it. One disadvantage is that it is time-consuming to construct a respondent's decision plan net, whereby the cost of using this method escalates rapidly.

These five contributions demonstrate that housing models are useful to assess the effects of changes in housing policy and/or changes in the housing market. Internationally oriented and international comparative research are precisely the areas where we would expect major growth in the application of housing models. Eventually, certain models will be the winners, as they prove to have the greatest utility; we should expect these superior models to find wider application. Of course, these models pose high demands on the quality of national housing statistics; the sources must be up to date and, especially, comparable. The Working Group 'Housing Models' of the European Network for Housing Research hopes to contribute to the further development, testing, and application of housing models, not only in the field of economics, but also in demography and policy studies. Interested persons are invited to contact the Working Group 'Housing Models' by writing to Johan Conijn, OTB, Thijsseweg 11, 2629 JA Delft, The Netherlands. 